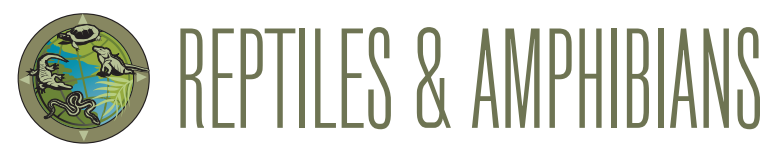

\title{
Predation on a Bocage's Wall Lizard (Podarcis bocagei) by a House Sparrow (Passer domesticus)
}

\author{
Cesar Ayres
}

AHE-Galicia, Barcelona 86 6C 36211, Vigo (Pontevedra), Spain (galicia@herpetologica.org)

$\mathrm{B}_{1}^{\mathrm{o}}$ ocage's Wall Lizard, Podarcis bocagei (López Seoane 885), which is endemic to northwestern Spain and Portugal (Galán 2015), is a ground-dweller that prefers open areas but also occupies rocky slopes and structures in areas with dense vegetation (Galán 1994).

At about 1200 h on 1 July 2021, I observed a female House Sparrow (Passer domesticus) preying on a Podarcis bocagei on a path crossing the dunes of Baluarte, Vigo (Pontevedra), Spain (29TNG27, datum ETRS89; elev. 5 m asl). The sparrow alternately grasped the lizard anteriorly and posteriorly, each time beating the lizard against the ground until it flew away with the prey in its beak to a house near the path (https://youtu.be/uIBKINDycg4).

House Sparrows are omnivorous, with a diet based mainly on plant material (especially seeds and fruits) supplemented with invertebrates. However, Anderson (2006) cited predation on reptiles and Howell and Clements (2019) reported predation on a Cuban Brown Anole (Anolis sagrei). During the breeding season in Spain, the portion of the diet composed of invertebrates increased to $9 \%$ of the diet by weight (Alonso 1985; Murgui 2016). The observation recorded herein occurred in the midst of the breeding season and at least two active nests where on the house to which the sparrow flew with its prey.

\section{Literature Cited}

Alonso, J.C. 1985. La alimentación del Gorrión Común Passer domesticus en áreas de cultivo de regadío extremeñas. Ardeola 32: 405-408.

Anderson, T.R. 2006. Biology of the Ubiquitous House Sparrow: From Genes to Populations. Oxford University Press, New York, New York, USA. https:// doi.org/10.1093/acprof:oso/9780195304114.001.0001.

Galán, P. 1994. Selección del microhábitat en una población de Podarcis bocagei del noroeste ibérico. Doñana Acta Vertebrata 21: 153-168.

Galán, P. 2015. Lagartija de Bocage - Podarcis bocagei (López Seoane, 1884). In: A. Salvador and A. Marco, (eds.), Enciclopedia Virtual de los Vertebrados Españoles Museo Nacional de Ciencias Naturales, Madrid, Spain. <http://www.vertebradosibericos.org/>.

Howell, H.J. and S.L. Clements. 2019. Consumption of vertebrate prey by the House Sparrow (Passer domesticus): An example of evolutionary responses to interspecific interactions within novel communities. The Wilson Journal of Ornithology 131: 406-410. https://doi.org/10.1676/18-118.

Murgui, E. 2016. Gorrión Común - Passer domesticus. (Linnaeus, 1758). In: A. Salvador and M. Morales (eds.), Enciclopedia Virtual de los Vertebrados Españoles Museo Nacional de Ciencias Naturales, Madrid, Spain. <http:// www.vertebradosibericos.org/>.

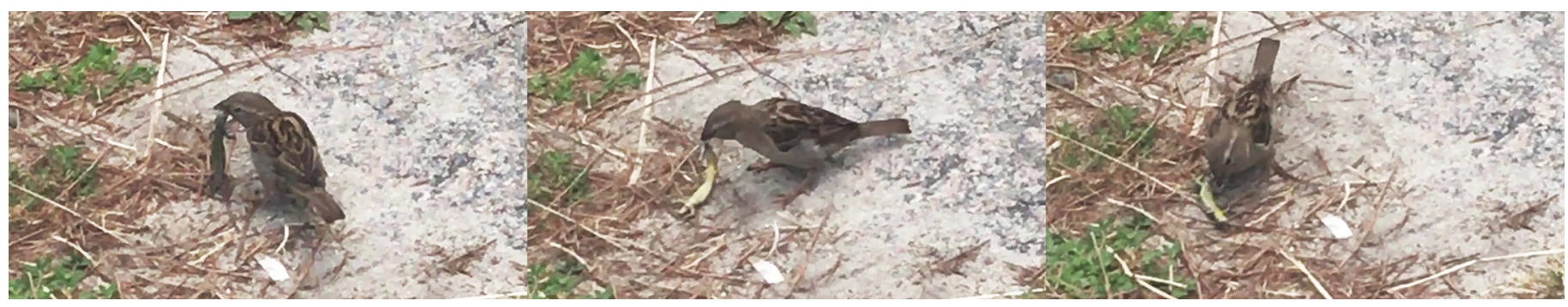

Fig. 1. Predation on a Bocage's Wall Lizard (Podarcis bocagei) by a House Sparrow (Passer domesticus) on a path crossing the dunes of Baluarte, Vigo (Pontevedra), Spain. From a video by the author. 